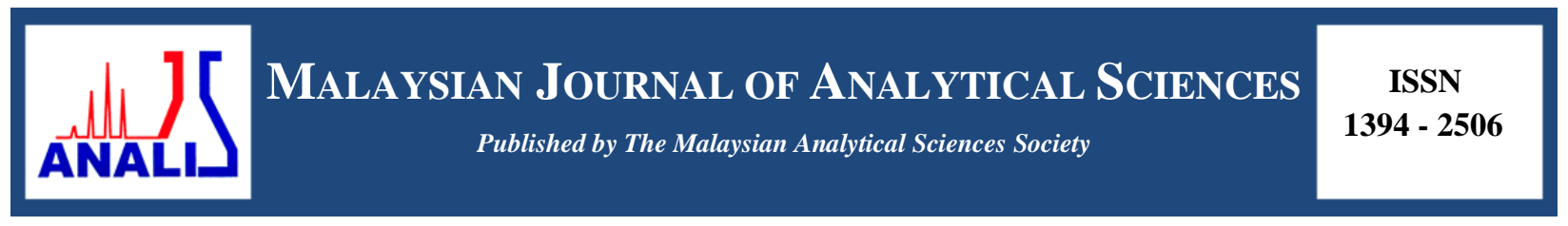

\title{
VENTILATION EFFECT ON THE RADON-222 ANNUAL EFFECTIVE DOSE INSIDE GUA GAJAH AND GUA PENYU CAVES, KOMPLEKS GUA KOTA GELANGGI, PAHANG, MALAYSIA
}

\author{
(Kesan Pengudaraan Kepada Dos Berkesan Tahunan Radon-222 dalam Gua Gajah dan Gua \\ Penyu, Kompleks Gua Kota Gelanggi, Pahang, Malaysia) \\ Nazree Ahmad ${ }^{1}$, Junaidah Md Sani ${ }^{1}$, Nur Hafilah Muslim ${ }^{1}$, Nur Amirah Alias ${ }^{1}$, Ahmad Saat $^{2}$ \\ ${ }^{I}$ Faculty of Applied Sciences \\ Universiti Teknologi MARA Pahang, 26400 Bandar Tun Abdul Razak Jengka, Pahang, Malaysia \\ ${ }^{2}$ Institute of Science, \\ Universiti Teknologi MARA, 40450 Shah Alam, Selangor, Malaysia \\ *Corresponding author: nazreeahmad@pahang.uitm.edu.my
}

Received: 4 December 2016; Accepted: 1 December 2017

\begin{abstract}
A study to determine the concentration and emanation rate of Radon-222 were done inside Gua Gajah and Gua Penyu limestone caves, Kompleks Gua Kota Gelanggi, Pahang, Malaysia to find the link between ventilation and annual effective dose. Gua Gajah has two major openings and features uneven earth surface unlike Gua Penyu which has single entrance and smooth passage way. Dosimeters with CR-39 solid state nuclear track detector (SSNTD) were distributed $15 \mathrm{~m}$ apart. For emanation rates, dosimeters were embedded about $5 \mathrm{~cm}$ into cave floor while for concentration measurements, they were placed $1 \mathrm{~m}$ above ground. The control samples were placed in front of the main entrance. The samples were left and collected after 30 days. Every CR-39 samples were etched with $6 \mathrm{M} \mathrm{NaOH}$ solution with $70^{\circ} \mathrm{C}$ for 6 hours in water bath and observed under microscope of 200x linear magnifications to calculate tracks densities. Results indicated that the average Radon-222 emanation rate inside Gua Gajah was higher than that of Gua Penyu. On the other hand, the average concentration of Radon-222 inside Gua Gajah was lower than that of Gua Penyu. The average annual effective dose of Radon-222 in Gua Gajah and Gua Penyu was $0.084 \mathrm{mSv}^{-1}$ and $0.12 \mathrm{mSv} \mathrm{yr}^{-1}$, respectively. These findings point out that ventilation contributed by cave openings plays an important role in reducing the indoor radon gas accumulation, thus lowering the annual effective dose.
\end{abstract}

Keywords: emanation rate, radon gas, radon concentration

\begin{abstract}
Abstrak
Kajian bagi mengukur kepekatan dan kadar pemancaran Radon-222 telah dijalankan dalam gua-gua batu kapur Gua Gajah and Gua Penyu, Kompleks Gua Kota Gelanggi, Pahang, Malaysia untuk mencari hubungan di antara pengudaraan dengan dos berkesan tahunan. Gua Gajah dengan dua laluan utama menunjukkan mukabumi tidak sekata manakala Gua Penyu hanya mempunyai satu laluan masuk dan rata. Dosimeter dengan pengesan jejak nuklear keadaan pepejal CR-39 (SSNTD) diletakkan berjarak $15 \mathrm{~m}$ satu sama lain. Dosimeter untuk kadar pemancaran ditanam $5 \mathrm{~cm}$ ke dalam lantai gua manakala bagi pengukuran kepekatan, dosimeter diletakkan $1 \mathrm{~m}$ di atas lantai gua. Sampel kawalan diletakkan di hadapan laluan masuk utama. Kesemua sampel ditinggalkan dan dikutip selepas 30 hari. Setiap sampel CR-39 kemudiannya dicelup dalam rendaman panas larutan 6M $\mathrm{NaOH}$ pada $70{ }^{\circ} \mathrm{C}$ selama 6 jam sebelum dicerap di bawah microskop 200x pembesaran linear untuk menentukan kepadatan trek. Hasil menunjukkan purata kadar pemancaran Radon-222 dalam Gua Gajah lebih tinggi berbanding Gua Penyu. Sebaliknya, purata kepekatan Radon-222 dalam Gua Gajah lebih rendah berbanding Gua Penyu. Dos berkesan tahunan Radon-222 untuk

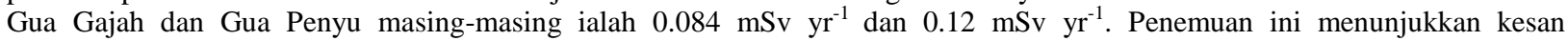




\section{Nazree et al: VENTILATION EFFECT ON THE RADON-222 ANNUAL EFFECTIVE DOSE INSIDE GUA GAJAH AND GUA PENYU CAVES, KOMPLEKS GUA KOTA GELANGGI, PAHANG, MALAYSIA}

pengudaraan daripada bukaan gua memainkan peranan penting dalam mengurangkan penumpukan radon gas dalaman seterusnya merendahkan nilai dos berkesan tahunan.

Kata kunci: kadar pemancaran, gas radon, kepekatan radon

\section{Introduction}

Radon is a naturally inert radioactive gas with a half-life of 3.824 days generated from the radioactive decay series of Uranium-238. It is the first decay product of Radium- 226 and a radioactive gas at room temperature. Radon is colorless, odorless and tasteless hence, does not give an immediate effect. However, if accumulated to higher levels in confined spaces radon gas may cause significant threat to human health especially when exposed in a long period of time [1], becoming the major contributor of radiation to the public [2]. The concentration of Radon-222 varies according to sites and geological materials [3] and its migration depends very much on the radioactivity concentration, porosity and permeability of the medium [4]. In addition, radon as a single atom gas easily diffuse through pores in soil, fractures in rocks and along other weak zone [5], such as shears, faults and thrust, increasing its migrating capability. In any air system, quantity of radon present depends upon the concentration of uranium in the local rock, atmospheric conditions and the extent of ventilation [6].

Gua Gajah and Gua Penyu caves at Kompleks Gua Kota Gelangi, are situated in Pahang, Malaysia located approximately at coordinate of $3^{\circ} 53^{\prime} 55.0^{\prime \prime} \mathrm{N} 102^{\circ} 28^{\prime} 30.7^{\prime \prime E}$. They are estimate 150 million years of age and mainly limestone marked by the internal formations of stalagmites and stalactites. These caves were about 100 meters long with inconsistence height between 20 to $30 \mathrm{~m}$. Gua Gajah features a two openings tunnel, a main entrance and another opening at the end of the cave which leads to a hillside. Therefore, visitors to Gua Gajah could enter the cave through main entrance and leave via the second opening at the passage end. However, this cave has uneven rock-strewn cave floor towards the passage exit. Gua Penyu on the other hand, has one opening that is the main entrance and smooth passageway throughout the wave tunnel. Hence, the apparent dissimilarity between these two caves is on the aspect of air circulation contributed by the number of openings existing in the cave passage. Figure 1 illustrates the features of Gua Gajah and Gua Penyu caves respectively.

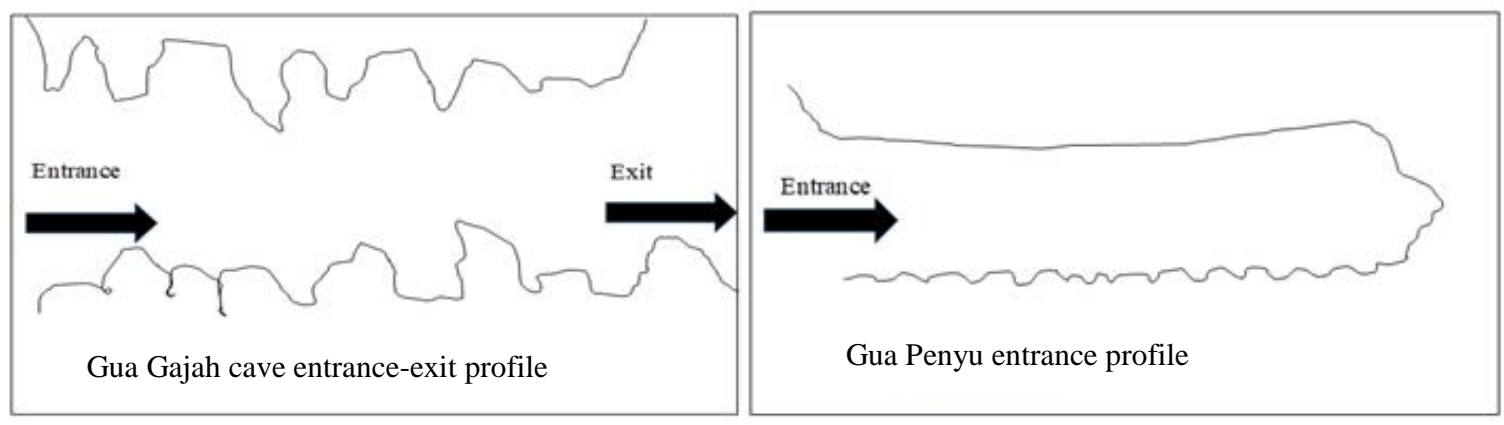

Figure 1. The sideview illustration of Gua Penyu and Gua Gajah caves entrance - exit profiles

In this investigation, the CR-39 solid-state nuclear track detector (SSNTD) used as the integrating detector of alpha particles from Radon-222. When an alpha particle struck the CR-39; the particle caused damage along its path that could be made visible by chemical etching [7]. These are called latent track that can be observed under a light transmission microscope with moderate magnification to calculate the track density. This was a passive technique which was very simple and economical, besides having ability for long term monitoring up to 12 months and has high registration sensitivity [8]. This research work aims to compare the emanation rates and concentration of Radon-222 as well as the annual effective dose between Gua Gajah and Gua Penyu caves. This finding will be used to verify the link between cave ventilation and accumulation of indoor radon gas as anticipated. 


\section{Materials and Methods}

The dosimeter was composed of polymer cup $4 \mathrm{~cm}$ in height with a lid of $7.5 \mathrm{~cm}$ diameter. A small hole about 16 $\mathrm{mm}$ diameter was made at the middle of its lid. It was then covered by a $5 \mathrm{~mm}$ thick soft sponge. The dosimeter was designed as such to ensure that only radon gas would diffuse into the chamber [9]. The $1.5 \mathrm{~cm}$ by $1.5 \mathrm{~cm}$ rectangular CR-39 detector was fixed at the bottom of the can using double sided tape. The dosimeter was then sealed neatly. The schematic diagram of the dosimeter as shown in Figure 2.

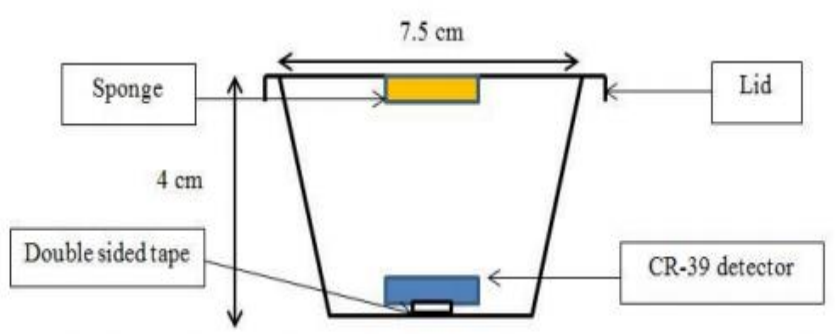

Figure 2. The schematic diagram of the radon dosimeter

Figure 3 shows the side view schematic diagram for sampling in each cave. Beginning at the main entrance, the sample locations were tagged L2 ascending to L12, consistently $15 \mathrm{~m}$ apart. A total of 22 dosimeters were placed inside each cave. For control experiment, a dosimeter for each cave was placed outdoor (L1) about $15 \mathrm{~m}$ from the main entrances. For determination of radon emanation rate, 11 units of dosimeter were embedded $5 \mathrm{~cm}$ in the soil while the remaining 11 dosimeters were placed $1 \mathrm{~m}$ above cave floor for the purpose of measuring radon gas concentration. Dosimeters that were placed in ground floor were positioned in such a way that the CR-39 was facing down. On the other hand, the wall for sticking the dosimeter was rubbed meticulously to make sure that the dosimeter remains intact throughout the sampling period. Each point was also visual recorded to facilitate the recollection of dosimeters. All dosimeters were then left and collected after a period of 30 days.

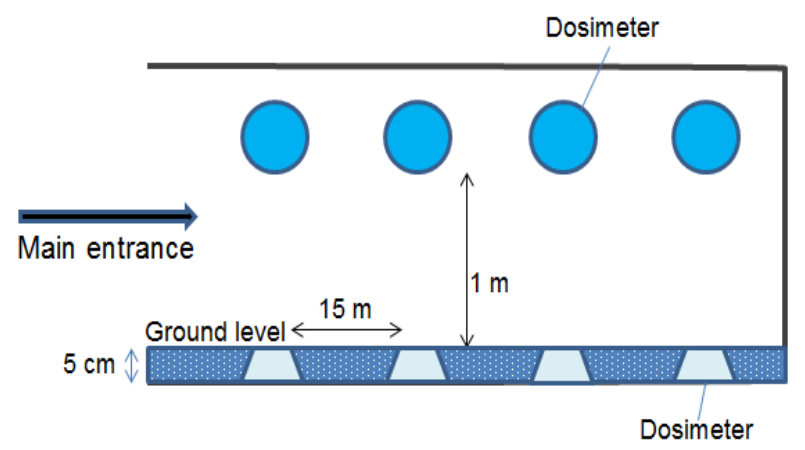

Figure 3. The side view illustration of the cave showing the method of sampling

During collection process, the dosimeters were kept in a container to secure the integrity of the samples. The CR-39 detectors underwent etching process by initially immersing them into a water bath containing $6 \mathrm{M}$ sodium hydroxide $(\mathrm{NaOH})$ solution at $70{ }^{\circ} \mathrm{C}$ for 6 hours. The detectors were then washed thoroughly with tap water for 1 hour before they were left to dry between tissue wipes and kept in airtight containers afterwards. The tracks were observed under the optical microscope with 200 times linear magnifications. The number of tracks of each detector was counted manually. Radon concentration was calculated according to Eq. (1) based on the number of visible spots on the CR-39 sheet. Only dark spots with diameter about $10 \mu \mathrm{m}$ were reckoned for calculation.

$$
\mathrm{C}_{\mathrm{Rn}}=\frac{\mathrm{D}}{\mathrm{Ft}}
$$




\section{Nazree et al: VENTILATION EFFECT ON THE RADON-222 ANNUAL EFFECTIVE DOSE INSIDE GUA GAJAH AND GUA PENYU CAVES, KOMPLEKS GUA KOTA GELANGGI, PAHANG, MALAYSIA}

$\mathrm{C}_{\mathrm{Rn}}$ was the radon concentration, $\mathrm{D}$ was the track density (tracks. $\mathrm{cm}^{-2}$ ), $\mathrm{t}$ was the exposure time (days) and $\mathrm{F}$ was the calibration factor (tracks $\mathrm{m}^{3} \mathrm{~cm}^{-2} \mathrm{~Bq}^{-1} \mathrm{~h}^{-1}$ ). The radon concentration in air was number of decays per second per cubic meter of air or $\mathrm{Bq} \mathrm{m}^{-3}$. According to [10], annual effective dose could be calculated using Eq. (2).

$$
\mathrm{E}=\mathrm{C} \times \mathrm{H} \times \mathrm{F} \times \mathrm{T} \times \mathrm{D}
$$

$\mathrm{C}$ was the radon concentration $\left(\mathrm{Bq} \mathrm{m}^{-3}\right), \mathrm{F}$ was the equilibrium factor, $0.4, \mathrm{H}$ was the occupancy factor, 0.8 , $\mathrm{T}$ was the number of hours in a year, $8760 \mathrm{~h}$ and $\mathrm{D}$ was the effective dose received by adults per unit Radon-222 or dose conversion factor $\left(9.0 \times 10^{-6} \mathrm{mSv} \mathrm{h}^{-1} \mathrm{~Bq} \mathrm{~m}{ }^{-3}\right)$. The Radon-222 emanation rate was calculated using Eq. (3).

$$
\mathrm{E}_{\mathrm{Rn}}=\frac{\mathrm{CV}}{\mathrm{At}}
$$

$\mathrm{E}_{\mathrm{Rn}}$ was the emanation rate $\left(\mathrm{Bq} \mathrm{m} \mathrm{m}^{-2} \mathrm{day}^{-1}\right), \mathrm{C}$ was the Radon-222 concentration $\left(\mathrm{Bq} \mathrm{m} \mathrm{m}^{-3}\right), \mathrm{V}$ was the volume of the polymer container $\left(\mathrm{m}^{3}\right)$, A was the surface area $\left(\mathrm{m}^{2}\right)$ of the lid and $\mathrm{t}$ was the exposure time (days).

\section{Results and Discussion}

Radon emanation rate is defined as the decaying radon atoms that have been released through an area per day. Figure 4 indicates an uneven distribution of emanation rates for both caves. However, the emanation rates for Gua Gajah were of higher values at most of the locations except at sampling locations L6 and L9. This finding was anticipated because Gua Gajah cave has more rocky features throughout its passage compared to Gua Penyu cave. Due to the fact that Uranium-226 as the major source for Radon-222 depends very much on the type of rock concealed underneath the cave floor, it is suggested that granitic rocks are present in this cave. Previous study by Aljarallah [11] reported that granite was a significant source of radon emanation. The emanation rate at the exit point of Gua Gajah is unexplainable. Nonetheless, it might be attributed to the granitic type of rock exist. The Radon-222 concentration for Gua Gajah and Gua Penyu caves are compared in Figure 5. Radon concentration is the specific radon activity per unit volume in the atmosphere. It indirectly represents the amount of floating radon gas in the air.

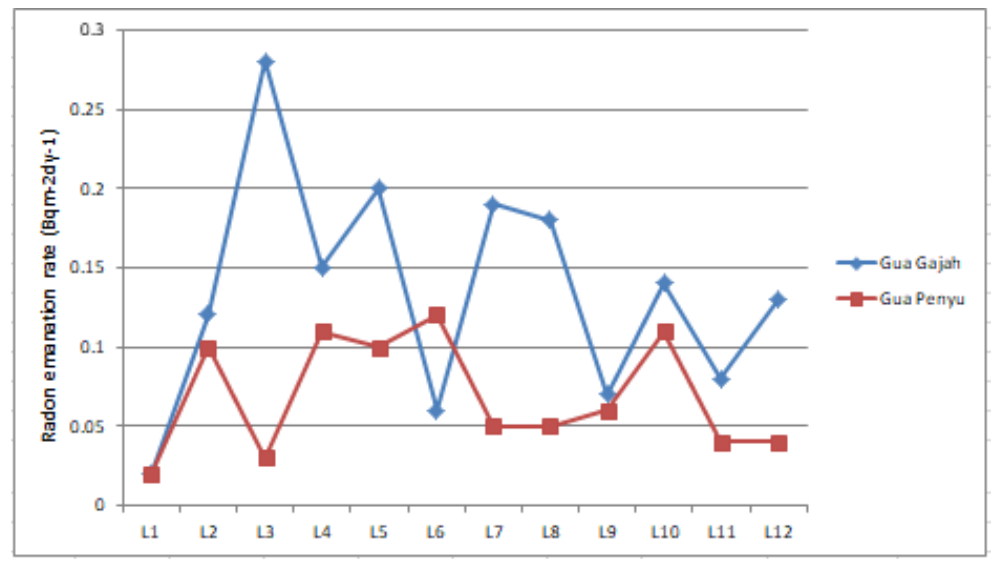

Figure 4. The Radon-222 emanation rates in Gua Gajah and Gua Penyu caves

The Radon-222 emanation rates between Gua Gajah and Gua Penyu caves are shown in Figure 5. The low concentration of radon at sampling point nearer to the main entrance of Gua Penyu was suggested a result of dilution and mixing of the gas with outdoor air. That near the end of its passage was suggested due to its poor ventilated feature. The lack of ventilation can permit high concentration of radon to build up in the trapped air. Gua Gajah on the other hand did not show apparent discrepancy between locations suggested due to the mixing of radon gas with air current between its two openings. Both caves indicated the value of Radon-222 concentrations lower than the indoor radon action level put forth by the International Commission on Radiological Protection (ICRP) 
[12], which is 200 to $600 \mathrm{~Bq} \mathrm{~m}^{-3}$. In average, the Gua Penyu cave which had only one opening showed noticeably higher concentration compared to that of Gua Gajah cave. This finding was dissimilar to that in Figure 4. It was suggested that the main reason for the differences was due to the variation in the natural ventilations. The average

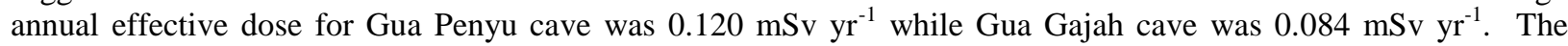
annual effective dose of Gua Gajah cave that has two openings was as anticipated, lower than that of Gua Penyu cave, which has single main entrance. This finding implies that ventilation plays an important part in reducing the average indoor radon gas content. The accumulation of indoor radon gas was hindered when there are ventilation holes, which allowed attenuation via dilution process.

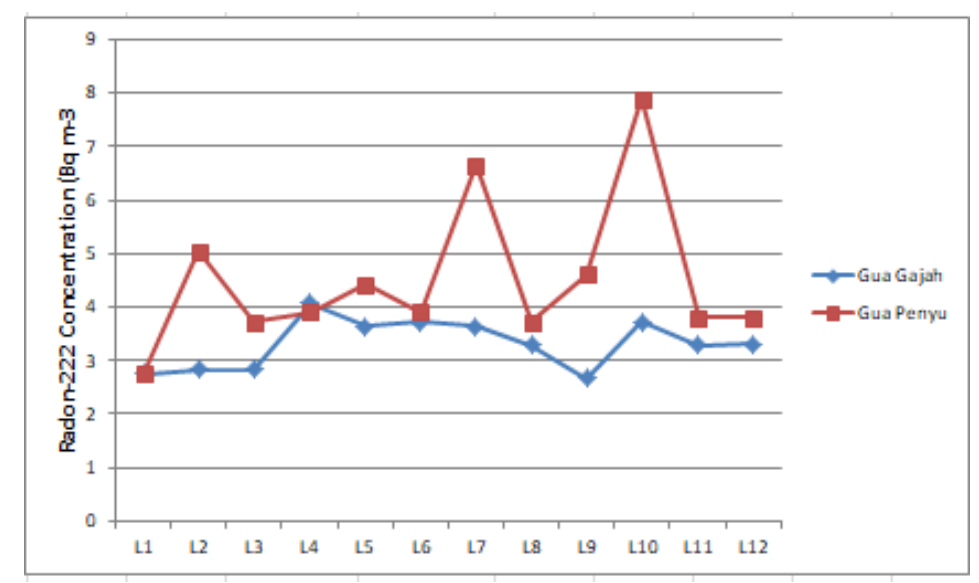

Figure 5. The concentrations of Radon-222 in Gua Gajah and Gua Penyu caves

\section{Conclusion}

From this study, it can be conclude that ventilation via cave openings plays an important role in reducing the indoor radon gas in a cave. Hence, more openings mean higher security in terms of breathing when occupying a cave. As far as human safety is concerned, it is very crucial for this study to be extend to other caves especially hotspot for tourism.

\section{Acknowledgement}

The writers would like to convey their greatest appreciation to the management of Tekam Felda Residence and Resort (Cave Division) and the Institute of Science, Universiti Teknologi MARA, Malaysia for their support and help during this study.

References
1. Field, M. S. (2007). Risks to cavers and cave workers from exposures to low-level ionizing $\alpha$ radiation from 222Rn decay in caves. Journal of Cave and Karst Studies, 69(1): 207-228.

2. Ahn, G. H. and Lee, J. K. (2005). Construction of an environmental radon monitoring system using CR-39 nuclear track detectors. Nuclear Engineering and Technology, 37(4): 395-400.

3. Mohamed, A. E. (2012). An overview on studying 222Rn exhalation rates using passive technique solid-state nuclear track detectors. American Journal of Applied Sciences, 9(10): 1653-1659.

4. Mansour, H. L., Tawfiq, N. F. and Karim, M. S. (2014). Indoor radon concentrations measurement in the dwellings of Thi-Qar governorate, Iraqi. Journal of Natural Sciences, 2(1): 19-26.

5. Alkhalifa, I. M., and Bakr, H. (2007). Determination of radon exhalation rates in Basrah Governorate (Iraq) using CR-39 solid state nuclear track detector (SSNTD’s). Basrah Journal of Science (A), 25(2): 97-104.

6. British Caving Association on Working Party (2012). Radon exposure during underground trips: A set of guidelines for caving and mining exploration. British caving association, Buxton.

7. Kadhum, N. F., Jebur, L.A. and Ridha, A. A. (2016). Studying different etching methods using CR-39 nuclear track detector. Scientific Research, 4: 45-53. 
Nazree et al: VENTILATION EFFECT ON THE RADON-222 ANNUAL EFFECTIVE DOSE INSIDE GUA GAJAH AND GUA PENYU CAVES, KOMPLEKS GUA KOTA GELANGGI, PAHANG, MALAYSIA

8. Farid, S. M. (2012). A study on the radon concentrations in Tobacco in Jeddah (Saudi Arabia) and the associated health effects. Medical Journal of Islamic World Academy of Sciences, 20(3): 84-93.

9. Hussein, Z. A., Jaafar, M. S., and Ismail, A. H. (2013). Measurements of indoor Radon-222 concentration inside Iraqi Kurdistan: Case study in the summer season. Journal of Nuclear Medicine \& Radiation Therapy, 4 (1):1-4.

10. Ahmad, S., Zaini, H., Zaharidah, A. B., Zuraidah, A. M., Siti, M. S and Misbah, H. (2010). Some remarks on diurnal radon concentration at various locations in Peninsular Malaysia. Journal of Nuclear and Related Technologies, 7(1): 49-57.

11. Aljarallah, M. I. (2001). Radon exhalation from granite used in Saudi Arabia. Journal of Environmental Radioactivity, 53(1): 91-98.

12. International Commission on Radiation Protection (1995). Protection against radon- 222 at home and at work. ICRP Publication, Pergamon, Oxford. 